\title{
Troels Fink \\ - som jeg har mødt ham
}

1912 - 18.april - 1992

af Poul Andersen

Den 18. april er en dato, der står fast i min hukommelse. Det er Dybbøldagen, min bryllupsdag og Troels Finks fødselsdag.

Det er 55 år siden, jeg fik min forste kontakt til Troels Fink. Han var ansat i den sønderjyske politiadjudantur, og jeg, der da boede i Højer, havde gjort nogle optegnelser, om hvorledes jorden var fordelt på danske og tyske hænder. Jeg sendte dem til ham og fik et venligt takkebrev, at det var et emne, der interesserede ham meget, og om han måtte låne mine notater et halvt år? Jeg har ikke set dem siden, men det er forlængst tilgivet.

Jeg havde aldrig truffet Troels Fink, men det skete nu kort efter, da jeg en dag var på besøg hos Hans Andersen, Kongsbjerg, for at gøre Landeværnet opmærksom på muligheden for eventuelt at købe nogle fenner i marsken, der var på tyske hænder. I den samtale vi havde ved vort første møde, blev jeg stærkt imponeret af hans nøje kendskab til forholdene i Højer og hans personalkendskab i Vestslesvig. Dette kendskab havde han erhvervet ved mange besøg, og det blev yderligere udvidet, da han var sekretær for det udvalg, der forberedte den danske indsats ved folketingsvalget i 1939. Valget blev en meget klar tilkendegivelse.

I 1940 blev »Grænseområdets danske Samfund « udvidet til »De sønderjyske danske Samfund«, som omfattede hele Nordslesvig, og her blev Troels Fink sekretær. Det var en betydelig indsats, der blev øvet af disse samfund i de spændingsfyldte år op til og under Anden Verdenskrig. Det var en dybt alvorlig, men også "- en skøn begejstrings tid-«, vor generation har haft den lykke at leve med $i$.

I Køllerperioden omkring 1900 var danskheden hårdt trængt. Det var i den situation, at hjuler Hans Jepsen Jefsen i Skærbæk skrev til redaktør Nicolai Svendsen på et brevkort: »Med danskheden står det ilde til. Men jeg tilser den dagligt«. I modsatning hertil kunne Troels Fink have skrevet til direktør Martin Hammerich, der var formand for Grænseområdets danske Samfund: "Jeg har tilset danskheden, der er grund til optimisme."

Så kom krigen og besættelsen, hvor vi ikke var i forbindelse. Han var på 
universitetet i Århus, blev professor, og mange opgaver blev lagt på hans skuldre.

Således var han Udenrigsministeriets konsulent i slesvigske spørgsmål. Blev administrator af godset Sandbjerg, der var blevet skænket til Århus Universitet. Underviste i Sønderjyllands historie, og var leder af kursus for journalister.

Til trods for de mange gøremål nåede han også at holde radioforedrag om Sønderjyllands historie, og der kom en lang række bøger fra hans flittige pen. I Gustav Aurings fortrinlige bibliografi over hans forfatterskab til 1982 har jeg optalt 16 bøger og pjecer, og flere er fulgt efter, så de fylder pænt på reolen. Endvidere 143 afhandlinger og artikler, samt 150 anmeldelser af både dansk og tysk litteratur om Sønderjyllands historie. Vil man sætte sig ind i disse særlige sider af vort lands historie, så har Troels Fink givet os læsestof til mange dage, ja måneder. Og vi finder det ikke blot i de selvstændige bøger, men også i Historisk Samfunds Årbøger, Sønderjysk Månedsskrift og tillige i Sprogforeningens Almanak, Flensborg Avis, Berlingeren m.fl.

Troels Fink er fuld af anekdoter og citater, og til et hvilket som helst emne,

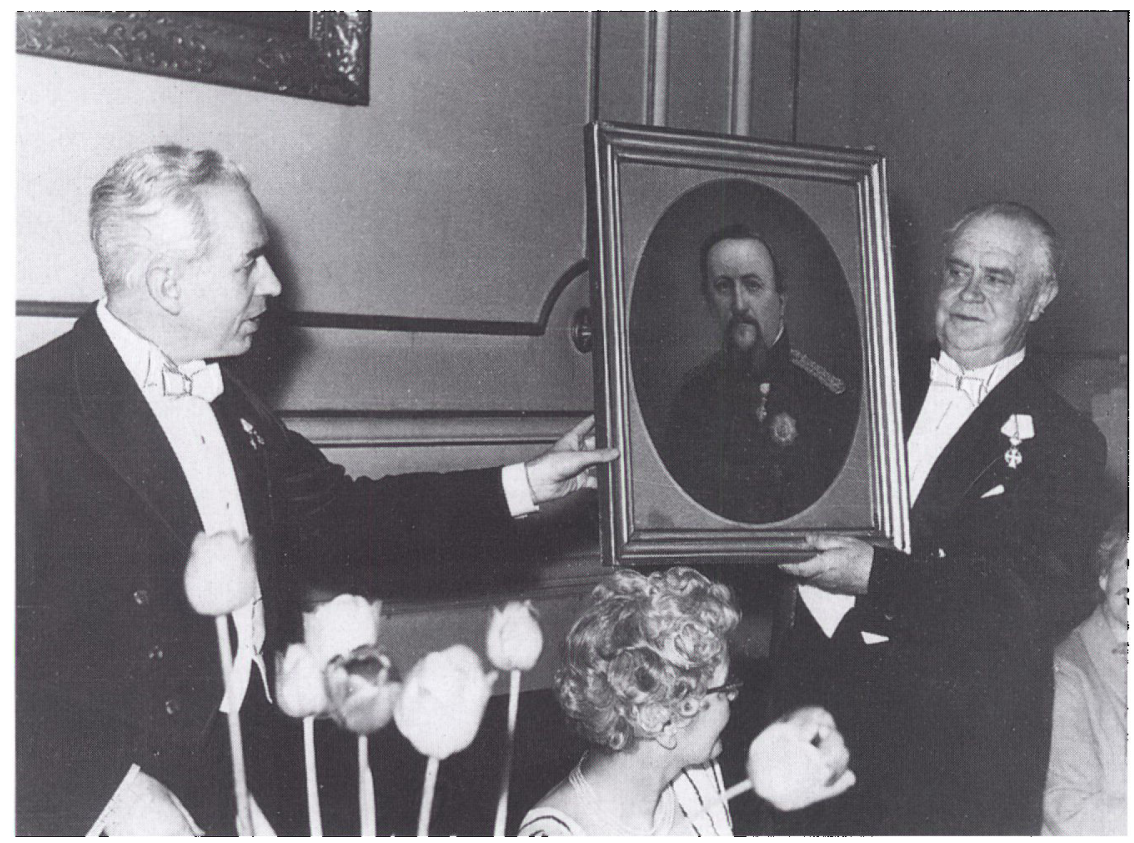

Arene som generalkonsul i Flensborg hød på mange opgaver, ogsa af reprasentativ art. Her overrakker Troels Fink et billede af Frederik VII til Borgerforeningens formand, rektor Dirk Dirks. Foto $1960 i$ Dansk Centralbibliotek for Sydslesvig. 
der debatteres, har han et citat fra Storm P., Piet Hein eller fortæller om en lille oplevelse på dejligt affenraask.

I 1959 forlod Troels Fink Århus og vendte tilbage til Sønderjylland, idet han blev generalkonsul i Flensborg, og med hans ekspertise på det sønderjyske område var det et lykkeligt valg, at han kom til at beklæde denne post. Det blev travle år, hvor han "tilså danskheden i Sydslesvig «. Bestandig var han på farten. I store forsamlinger, i små forsamlingshuse, gjorde sig bekendt med befolkningen og var en god støtte i det danske arbejde gennem de næste 17 år.

$\mathrm{Nu}$ var vi blevet naboer ved Flensborg fjord, ganske vist på hver sin side af grænsen, men fik bedre lejlighed til at mødes, og jeg lærte en skik, der nu er blevet fast her i huset. Ved et formiddagsbesøg på Generalkonsulatet blev der serveret formiddagskaffe og dertil et stykke chokolade, og siden får jeg daglig samme traktement om formiddagen. I sin tid som generalkonsul indbød Troels Fink til reception på Majestætens fødselsdag. Det var et par hyggelige timer, hvor man modtes med gæster fra begge sider af Skelbækken. En tradition var det også, at studenterne fra Duborgskolen, når de havde fået den hvide hue, fik en lykønskning af Troels Fink på Generalkonsulatet.

Helt sikkert var det, at vi traf hinanden til Landeværnets generalforsamling. I mange år hørte vi til de yngste medlemmer; vi fik begge andele, da Landevær-

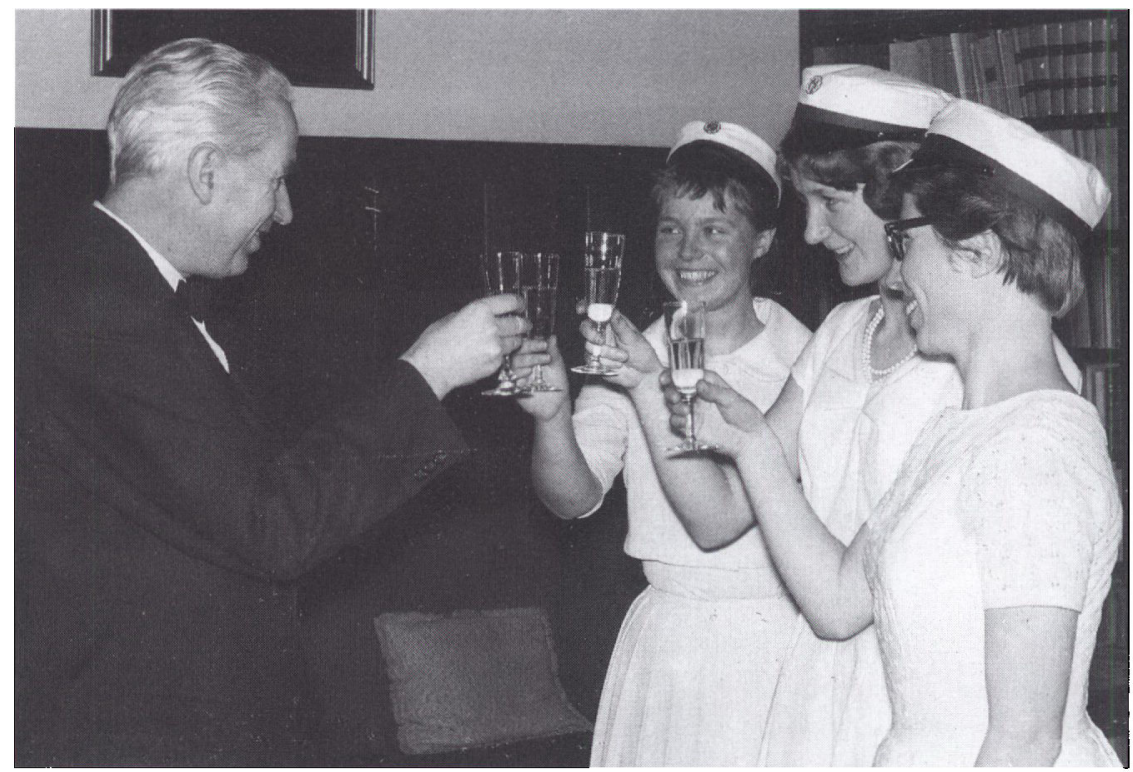

Alle med et glimt i øjet ... Troels Fink hilser på nybagte studiner fra Duborg-Skolen ved modtagelsen på generalkonsulatet. Foto i Dansk Centralbibliotek for Sydslesvig. 
net blev oprettet i 1927, nu er vi blandt de ældste. Men vi har oplevet at træffe »den gamle garde«: Hans Andersen, direktør Callø, Jefsen-Christensen, amtmand Refslund Thomsen og Henrik Petersen, Korntved, for blot at nævne enkelte af dem, der trofast mødte op den første tirsdag i marts år efter år.

Andre steder kunne vi også træffe sammen, men pudsigt var det, at min kone og jeg på en ferietur til London $i$ denne millionbys menneskemylder pludselig stod over for Troels Fink, der var i London, for i det engelske rigsarkiv at hente stof til sit store værk »Da Sønderjylland blev delt«. Vi besluttede at fejre mødet med at spise middag sammen, og havde tre fornøjelige timer sammen.

Skovarbejde er godt for sjal og legeme, mener Troels Fink - her $i$ arbejdstojet sammen med sin fatter Gudmund. Foto 1990 i privateje.

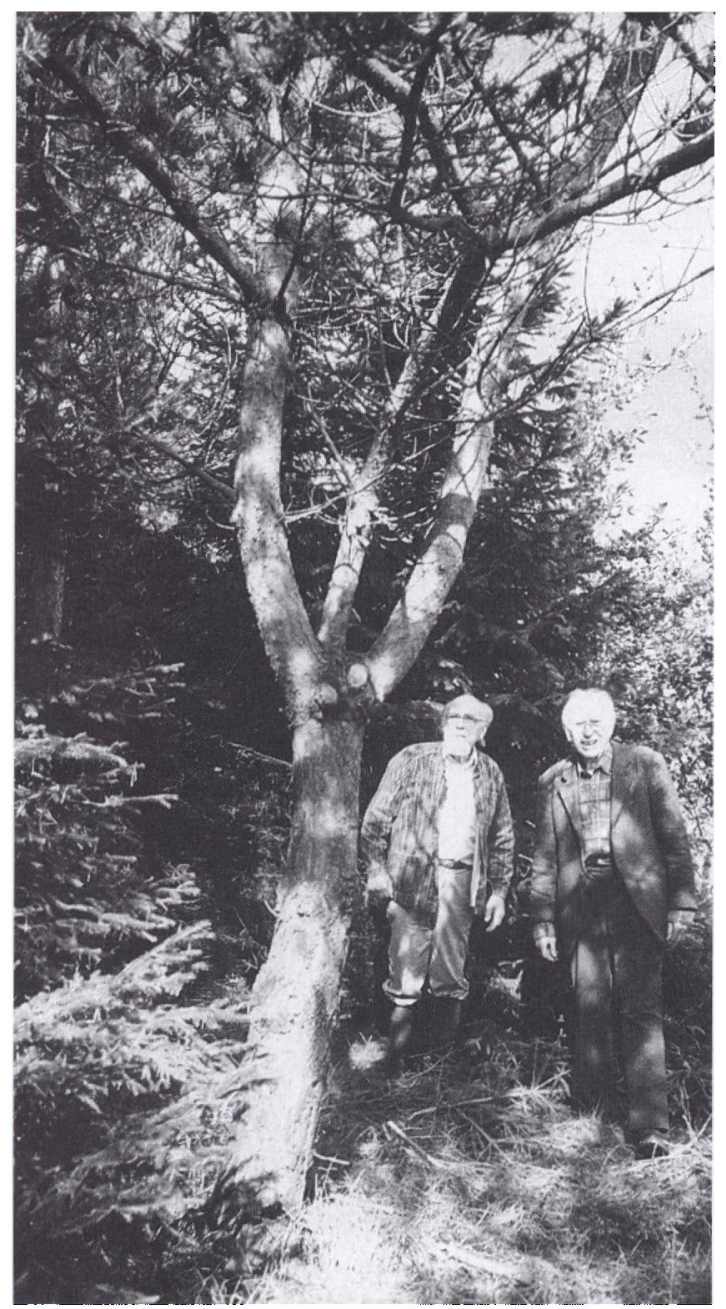


Efter 17 års højt respekteret indsats som generalkonsul vendte Troels Fink tilbage til barndomsbyen, dog ikke for at sidde med hænderne i skødet. Et nyt initiativ var oprettelsen af Institut for Grænseregionsforskning, hvis direktør han var fra 1976 til 1979, og her udkom det ovenfor nævnte store trebinds værk "Da Sønderjylland blev delt«.

Men Troels Fink har andre talenter end historieskrivning. I 1964 havde han købt en nedlagt gård på mager jord $\mathrm{i}$ nærheden af Bajstrup. På gårdens sandede marker begyndte han at plante fyr og gran, og resultatet er i dag en stor og smuk plantage, hvor han næsten hver dag får frisk luft og motion. Sammen har vi plantet $i$ hundredvis af træer. På den årlige sommerudflugt med madkurv til plantagen går vi på inspektion og glæder os over, at træerne trives vel.

Men også på Vægterpladsen skal det gro i hans stuer. Ikke ganske almindelige potteplanter, men sjældne vækster, som han glæder sig over, når de folder sig ud. Det samme galder i den hyggelige lille gårdhave, hvor der er forskellige beplantninger, og lidt stolt kan han her plukke mandler og figner. Denne interesse for at se tingene gro og arbejde i skov og have vidner om, at han har rod i en slægt, der havde jord under neglene.

Det er dog ikke kun spade, økse og sav han kan bruge. Også i køkkenet er han kyndig og kan servere selvkomponerede retter. Grøntsager sætter han højt, og en gulerod køber han dagligt, men en dag bad han om to. Grønthandleren studsede, og spurgte så "Ska do ha party?«. Et sådant spørgsmål kan Troels Fink rigtig goutere. Og især sætter han pris på at genfortælle historien - på affenraask.

Det er imponerende, hvad han overkom, og altid parat til at hjælpe med gode råd og ideer. $\mathrm{Og}$ da Historisk Samfunds mangeårige formand ønskede at samle sig om andre opgaver, var Troels Fink straks parat til at overtage formandsposten for to år. Det blev imidlertid 5 år.

Et andet eksempel er, at han i efteråret 1982 sagde ja til at holde fire foredrag om Sønderjyllands historie i Treja, en af vore sydligste forposter. Men da mørkekørsel ikke er hans livret, tilbød jeg at være chauffør. Det blev fire vellykkede aftner. Det var meget opmærksomme tilhørere, der havde stor spørgelyst. På turene frem og tilbage fik vi gode samtaler. Emnerne var Nordog Sydslesvig, det kan vi vist aldrig blive færdige med. For mit vedkommende, der er amatør på den historiske ager, høstede jeg megen viden.

Dette gælder også de omtrent månedlige besøg af Troels Fink, hvor vi taler om grænselandets historie fra spændingens år i trediverne og op til dato. Vi har fælles minder og bekendte, og stadig er det Sønderjylland, der optager os mest. 
